\title{
Cytotoxicity, antimicrobial and antioxidant activity of eight compounds isolated from Entada abyssinica (Fabaceae)
}

\author{
Jean P. Dzoyem ${ }^{1,2^{*}}$, Raduis Melong ${ }^{3,4}$, Armelle T. Tsamo ${ }^{3}$, Alembert T. Tchinda ${ }^{5}$, Deccaux G. W. F. Kapche ${ }^{4}$,
} Bonaventure T. Ngadjui ${ }^{3}$, Lyndy J. McGaw ${ }^{1}$ and Jacobus N. Eloff ${ }^{1}$

\begin{abstract}
Background: Entada abyssinica is a plant traditionally used against gastrointestinal bacterial infections. Eight compounds including three flavonoids, three terpenoids, a monoglyceride and a phenolic compound isolated from $E$. abyssinica were investigated for their cytotoxicity, antibacterial and antioxidant activity.

Results: Compounds $\mathbf{7}$ and $\mathbf{2}$ had remarkable activity against Salmonella typhimurium with the lowest respective minimum inhibitory concentration (MIC) values of 1.56 and $3.12 \mu \mathrm{g} / \mathrm{mL}$. The antioxidant assay gave $\mathrm{IC}_{50}$ values varied from 0.48 to $2.87 \mu \mathrm{g} / \mathrm{mL}$ in the 2,2-diphenyl-1-picrylhydrazyl (DPPH) assay, from 2.53 to $17.04 \mu \mathrm{g} / \mathrm{mL}$ in the 2,2'-Azinobis (3-ethylbenzothiazoline-6-sulphonic acid) diammonium salt (ABTS) assay and from 1.43 to $103.98 \mu \mathrm{g} / \mathrm{mL}$ in the FRAP assay. Compounds had relatively low cytotoxicity ( $\mathrm{LC}_{50}$ values ranging from 22.42 to $80.55 \mu \mathrm{g} / \mathrm{mL}$ ) towards Vero cells. Ursolic acid had the most potent cytotoxicity against THP-1 and RAW 264.7 cells with LC $\mathrm{C}_{50}$ values of 9.62 and $4.56 \mu \mathrm{g} / \mathrm{mL}$ respectively, and selectivity index values of 7.32 and 15.44 respectively.
\end{abstract}

Conclusion: Our findings suggest that among the terpenoid and flavonoid compounds studied, entadanin (compound 7) possess tremendous antibacterial activity against S. typhimurium and could be developed for the treatment of bacterial diseases.

Keywords: Cytotoxicity, Antibacterial, Free radical scavenging, Entada abyssinica

\section{Background}

Oxidative stress occurs when there is excessive free radical production and/or low antioxidant defense, which leads to many pathophysiological conditions in the body [1]. To neutralize free radicals and protect the body against oxidative damage, different antioxidants which are present in normal physiological conditions are able to counteract the production of reactive oxygen species. Free radicals are known to be the main cause of various diseases such as cancer and bacterial diseases. The development of resistance to multiple drugs in microbes and tumor cells has become a major public health threat [2, $3]$. Cancer is one of the leading causes of death in most

\footnotetext{
*Correspondence: jpdzoyem@yahoo.fr

2 Department of Biochemistry, Faculty of Science, University of Dschang, P.O. Box 67, Dschang, Cameroon

Full list of author information is available at the end of the article
}

well developed countries. A large body of evidence has determined that relationships exist among certain bacteria and cancers [4]. Because of the resistance that pathogenic microorganisms and malignant cells build against current antibiotics and anticancer drugs, there is great interest in the search for new therapeutic agents. Thus, in recent years there has been increased use of plants and their derivatives as an alternative modality in the treatment of various diseases, including cancer and infections caused by microorganisms [5]. Unlike synthetic drugs, bioactive natural products can have a beneficial effect on the whole organism and with less toxic effects. Therefore, natural products will continue to be extremely important as sources of discovery of new medicinal agents. Entada abyssinica A.Rich (Fabaceae) is a tree widely spread in tropical Africa. It is traditionally used to treat coughs, rheumatism, bronchitis, abdominal pains, diarrhoea and 
fever and to prevent miscarriage [6, 7]. Some pharmacological properties of $E$. abyssinica have been previously reported, including anti-inflammatory, antimicrobial and antioxidant [8-10]. Previous phytochemical screening of E. abyssinica indicated the presence of flavonoids, terpenoids and kolavic acid derivatives [11-13]. Considering the vast potential of plants as sources of antimicrobial and anticancer drugs, the objective of this study was to examine the possible antiproliferative, antimicrobial and antioxidant activity of terpenoid and flavonoid compounds isolated from $E$. abyssinica.

\section{Methods}

\section{Chemicals and compounds}

Gentamicin was obtained from Virbac, South Africa. Sodium carbonate was provided by Holpro Analytic, South Africa. Dulbecco's Modified Eagle Medium (DMEM) and Fetal calf serum (FCS) were purchased from Highveld Biological, South Africa. Whitehead Scientific, South Africa provided trypsin and Phosphate buffered saline (PBS). $p$-iodonitrotetrazolium violet (INT), doxorubicin, 2,2-diphenyl-1-picrylhydrazyl
(DPPH), 3-(4,5-dimethylthiazol-2-yl)-2,5-diphenyltetrazolium bromide (MTT), puromycin, 2,2'-Azino-bis (3-ethylbenzothiazoline-6-sulphonic acid) diammonium salt (ABTS), dimethyl sulfoxide (DMSO), were provided by Sigma-Aldrich St. Louis, MO, USA, while Müller-Hinton agar and broth were from Sigma-Aldrich, India.

Naturally occurring compounds studied in this work were isolated from the leaves and stembark of Entada abyssinica. The leaves of E. abyssinica was collected in May 2012 at Balatchi (Mbouda), in the West region of Cameroon, and identified by Mr. Victor Nana (plant taxonomist) of the National Herbarium of Cameroon, Yaoundé, where a voucher specimen is deposited under reference number $32436 / \mathrm{HNC}$. Compounds studied included: ursolic acid (1), quercetin-3-O- $\alpha$-L-rhamnoside or quercitrin (2), quercetin-3-O- $\beta$-D-glucosyl $(1 \rightarrow 4)$ - $\alpha$-L-rhamnoside (3), (8S)-kolavic acid 15-methyl ester (4), 13,14,15,16-tetranor-3-clerodene-12,18-dioic acid (5), methyl gallate (6), entadanin (7), bis-[(S)-(2,3dihydroxypropyl)] hexacosanedioate (8). We previously described their isolation procedure and their structure elucidation [14]. Chemical structures are shown in Fig. 1.

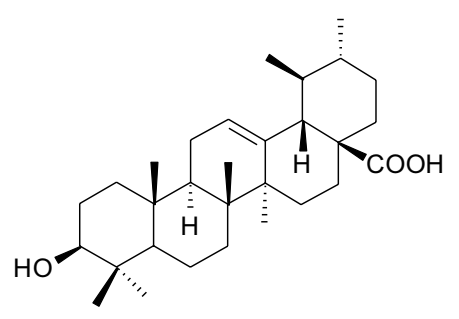

(1)<smiles>O=c1c(O)c(-c2ccc(O)c(O)c2)oc2cc(O)cc(O)c12</smiles>

(2)

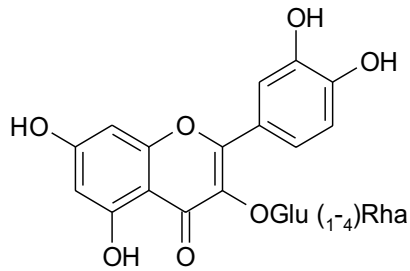

(3)<smiles>COC(=O)/C=C(/C)CCC1[C@H](C)CC[C@H]2C(C(=O)O)=CCC[C@H]12</smiles>

(4)<smiles>C[C@@H]1CCC2C(C(=O)O)=CCC[C@H]2[C@H]1CC(=O)O</smiles>

(5)<smiles>CC(=O)c1cc(O)c(O)c(O)c1</smiles>

(6)<smiles>COc1c(O)c(O)cc2c1COc1c-2oc2cc(O)cc(O)c2c1=O</smiles>

(7)<smiles>O=C(CCCCCCO)OCC(O)CO</smiles>

(8)

Fig. 1 Chemical structures of ursolic acid (1), quercetin-3-O-a-L-rhamnoside or quercitrin (2), quercetin 3-O- $\beta$-D-glucosyl (1 $\rightarrow$ 4)-a-L-rhamnoside (3), (8S)-kolavic acid 15-methyl ester (4), 13,14,15,16-tetranor-3-clerodene-12,18-dioic acid (5), methyl gallate (6), entadanin (7), bis-[(S)-(2,3-dihydroxypropyl)] hexacosanedioate (8) 


\section{Antimicrobial activity}

The six bacterial strains included: Pseudomonas aeruginosa ATCC 27853, Bacillus cereus ATCC 14579, Staphylococcus aureus ATCC 29213, Escherichia coli ATCC 25922, Salmonella typhimurium ATCC 14028 and Enterococcus faecalis ATCC 29212. The antimicrobial activity was evaluated by determining the minimal inhibitory concentration (MIC) by the rapid $p$-iodonitrotetrazolium violet (INT) microdilution method as previously described [15].

\section{Antioxidant assays \\ ABTS radical assay}

The antioxidant activity by ABTS was assessed according to the method previously described [16].

\section{DPPH assay}

The DPPH radical-scavenging activity was assessed by the method previously described [16].

\section{Ferric reducing antioxidant power (FRAP) assay}

The antioxidant activity by the ferric reducing antioxidant power (FRAP) was assessed according to the method previously described with slight modifications [16].

\section{Cytotoxicity assay \\ Cell culture}

Cancer cell lines including human monocytic THP-1 and murine macrophage RAW 264.7 cells and the normal mammalian Vero monkey kidney cell line were obtained from the American Type Culture Collection (Rockville, MD, USA). They were maintained in DMEM under standard cell culture conditions at $37^{\circ} \mathrm{C}$ and $5 \% \mathrm{CO}_{2}$ in a humidified environment.

\section{MTT assay}

The 3-(4,5-dimethylthiazol-2-yl)-2,5-diphenyltetrazolium bromide (MTT) assay was used to determine the cytotoxicity of the compounds as previously described [15]. The selectivity index (SI) values to identify selective anti-cancer cell activity were calculated by dividing the $\mathrm{LC}_{50}$ values of normal Vero cells by the $\mathrm{LC}_{50}$ of cancer cells.

\section{Statistical analysis}

Experiments were performed three times and values were expressed as mean \pm standard deviation. Differences between $\mathrm{IC}_{50}$ values were analysed for statistical significance using ANOVA and compared using the Fisher's least significant difference (LSD) at 5\% interval confidence.

\section{Results}

The structures of compounds isolated from E. abyssinica (Fig. 1) were established based on spectroscopic data and direct comparison with previously published data. Their antibacterial activity results are presented in Table 1 . The overall results showed that compounds presented variable antibacterial activity with MIC values ranged between 1.56 and $100 \mu \mathrm{g} / \mathrm{mL}$. Gram-positive bacteria were more sensitive than the Gram-negative bacteria. In particular S. typhimurium had the highest susceptibility to the compounds with the lowest MIC values of $1.56 \mu \mathrm{g} / \mathrm{mL}$ followed by B. cereus (MIC values of $6.25 \mu \mathrm{g} /$ $\mathrm{mL}$ ). Compounds 7 and $\mathbf{2}$ had the most potent antibacterial activity against $S$. typhimurium with MIC values of 1.56 and $3.12 \mu \mathrm{g} / \mathrm{mL}$ respectively and moderate activity against $S$. aureus $(\mathrm{MIC}=12.5 \mu \mathrm{g} / \mathrm{mL}$ ). Similarly, compound 1 (ursolic acid) had significant activity against $B$. cereus $(\mathrm{MIC}=6.25 \mu \mathrm{g} / \mathrm{mL})$.

Table 1 Antibacterial activity of eight compounds isolated from Entada abyssinica (MIC in $\mu \mathrm{g} / \mathrm{mL}$ )

\begin{tabular}{|c|c|c|c|c|c|c|}
\hline \multirow[t]{2}{*}{ Compounds } & \multicolumn{6}{|c|}{ MIC ( $\mu \mathrm{g} / \mathrm{mL})$} \\
\hline & $\mathrm{Sa}$ & $B C$ & $S t$ & $\mathrm{~Pa}$ & $E f$ & $E c$ \\
\hline 1 & 12.5 & 6.25 & 100 & - & - & - \\
\hline 2 & & 12.5 & 3.12 & 50 & 25 & 50 \\
\hline 3 & 25 & 50 & 25 & 50 & 50 & 25 \\
\hline 4 & 25 & 25 & 100 & - & - & - \\
\hline 5 & - & - & - & - & - & - \\
\hline 6 & 50 & 50 & 25 & - & - & - \\
\hline 7 & 12.5 & 25 & 1.56 & 25 & - & 12.5 \\
\hline 8 & - & - & - & - & - & - \\
\hline Gentamicin & 0.5 & 0.5 & 2 & 0.25 & 0.25 & 1 \\
\hline
\end{tabular}

- 100 mg/mL. Sa Staphylococcus aureus, Ef Enterococcus faecalis, Bc Bacillus cereus, Ec Escherichia coli, Pa Pseudomonas aeruginosa, St Salmonella typhimurium 
For the antioxidant activity, samples were tested at several concentrations, then from the dose-response activities, the $\mathrm{IC}_{50}$ values were obtained and are presented in Table 2. The $\mathrm{IC}_{50}$ values for the different compounds ranged from 0.48 to $2.87 \mu \mathrm{g} / \mathrm{mL}$ in the $\mathrm{DPPH}$ assay, from 2.53 to $17.04 \mu \mathrm{g} / \mathrm{mL}$ in the ABTS assay and from 1.43 to $103.98 \mu \mathrm{g} / \mathrm{mL}$ in the FRAP assay.

For the cytotoxicity, the $\mathrm{LC}_{50}$ values were determined and the selectivity index (SI) values were calculated and presented in Table 3. A perusal of Table 3 shows that compounds were less toxic than the positive control ( $\mathrm{LC}_{50}$ values ranging from 22.42 to $80.55 \mu \mathrm{g} / \mathrm{mL}$ ) towards the Vero cells suggesting relative lack of cytotoxicity. The anti-proliferative activity against cancer cell lines showed that compounds had $\mathrm{LC}_{50}$ values ranging from 9.62

Table 2 Antioxidant activity of eight compounds isolated from Entada abyssinica

\begin{tabular}{llll}
\hline Compounds & $\begin{array}{l}\text { DPPH }\left(\mathbf{I C}_{\mathbf{5 0}}, \boldsymbol{\mu g} /\right. \\
\mathbf{m L})\end{array}$ & $\begin{array}{l}\text { ABTS }\left(\mathbf{I C}_{\mathbf{5 0}}, \boldsymbol{\mu \mathbf { g }} /\right. \\
\mathbf{m L})\end{array}$ & $\begin{array}{l}\text { FRAP }(\boldsymbol{\mu m o l} \\
\left.\mathrm{FeSO}_{\mathbf{4}} / \mathbf{g}\right)\end{array}$ \\
\hline $\mathbf{1}$ & $2.87 \pm 1.19^{\mathrm{a}}$ & $7.04 \pm 1.29^{\mathrm{a}}$ & $1.43 \pm 0.80^{\mathrm{a}}$ \\
$\mathbf{2}$ & $0.9 \pm 0.06^{\mathrm{b}}$ & $3.53 \pm 0.39^{\mathrm{b}}$ & $76.01 \pm 1.10^{\mathrm{b}}$ \\
$\mathbf{3}$ & $2.08 \pm 0.19^{\mathrm{a}}$ & $17.04 \pm 0.26^{\mathrm{c}}$ & $75.34 \pm 1.06^{\mathrm{b}}$ \\
$\mathbf{4}$ & - & - & $1.93 \pm 0.14^{\mathrm{a}}$ \\
$\mathbf{5}$ & - & - & $5.09 \pm 0.40^{\mathrm{c}}$ \\
$\mathbf{6}$ & $0.48 \pm 0.02^{\mathrm{c}}$ & $2.53 \pm 0.49^{\mathrm{d}}$ & $103.98 \pm 13.70^{\mathrm{d}}$ \\
$\mathbf{7}$ & $1.12 \pm 0.10^{\mathrm{c}, \mathrm{d}}$ & $4.13 \pm 0.10^{\mathrm{e}}$ & $72.41 \pm 2.02^{\mathrm{b}, \mathrm{e}}$ \\
$\mathbf{8}$ & - & - & $22.98 \pm 4.29^{f}$ \\
Trolox & $8.71 \pm 2.03^{\mathrm{e}}$ & $10.38 \pm 2.4^{\mathrm{a}, \mathrm{f}}$ & $\mathrm{nd}$ \\
Ascorbic acid & $3.44 \pm 1.9^{\mathrm{a}, \mathrm{f}}$ & $4.15 \pm 1.21^{\mathrm{d}, \mathrm{e}}$ & $\mathrm{nd}$ \\
\hline
\end{tabular}

Data represent the mean \pm SD of three independent experiments; values with different letters are significantly different at $\mathrm{p}<0.05$

nd not determined, $-100 \mu \mathrm{g} / \mathrm{mL}$ to $>100 \mu \mathrm{g} / \mathrm{mL}$ and the SI ranged from 0.84 to 7.32 on THP- 1 cells. For RAW 264.7 cells, the $\mathrm{LC}_{50}$ values varied from 4.56 to $86.55 \mu \mathrm{g} / \mathrm{mL}$ and the SI ranged from 0.81 to 15.44 . Compound 1 had the most potent cytotoxicity against THP-1 and RAW 264.7 cells with $\mathrm{LC}_{50}$ values of 9.62 and $4.56 \mu \mathrm{g} / \mathrm{mL}$ respectively.

\section{Discussion}

The antibacterial potential ranged from significant to weak activity. Ursolic acid is an ubiquitous compound that can be isolated from many medicinal plants and its antibacterial activities are well documented. It has been reported to be active against many bacterial species, particularly Gram-positive species, inhibiting bacterial growth of S. aureus with a MIC value of $4 \mu \mathrm{g} / \mathrm{mL}[17,18]$. It is noteworthy that the activity of compound 7 (entadanin) against $S$. typhimurium was comparable to the standard gentamicin. Quercitrin is a quercetin-related flavonoid and previous studies have shown that quercetin and its glycosides quercetin-3-O- $\alpha$ - $\mathrm{L}$-arabinopyranoside and quercetin-3-O- $\beta$-D-arabinopyranoside have strong antibacterial activity against the Gram-positive $S$. aureus, and the Gram-negative $P$. aeruginosa and $E$. coli with MIC values ranged from 0.093 to $0.37 \mu \mathrm{g} / \mathrm{mL}$ [19].

The antioxidant activity of compounds can be determined in vitro by hydrogen atom transfer (HAT) method and single electron transfer (SET) method. HAT methods measure the capacity of an antioxidant to scavenge free radicals by hydrogen donation to form a stable compound. SET methods determine the ability of the antioxidant to transfer one electron to reduce compounds including metals, carbonyls and radicals [20]. The FRAP assay involves the SET method, while the DPPH and ABTS assays involve both methods, but predominantly

Table 3 Cytotoxicity ( $\mathrm{LC}_{50}$ in $\mu \mathrm{g} / \mathrm{mL}$ ) of eight compounds isolated from Entada abyssinica and their selectivity index (SI) values against normal and cancer cell lines

\begin{tabular}{|c|c|c|c|c|c|}
\hline \multirow[t]{2}{*}{ Compounds } & \multirow[t]{2}{*}{ Vero $\mathrm{LC}_{50}$} & \multicolumn{2}{|l|}{ THP-1 } & \multicolumn{2}{|l|}{ RAW 264.7} \\
\hline & & $\mathrm{LC}_{50}$ & SI & $\mathrm{LC}_{50}$ & SI \\
\hline 1 & $22.42 \pm 2.48^{\mathrm{a}}$ & $9.62 \pm 0.59^{\mathrm{a}}$ & 7.32 & $4.56 \pm 0.020^{\mathrm{a}}$ & 15.44 \\
\hline 2 & $44.83 \pm 2.83^{b}$ & - & nd & $16.44 \pm 0.20^{b}$ & 4.28 \\
\hline 3 & $53.76 \pm 2.05^{c}$ & - & nd & $41.90 \pm 0.43^{c}$ & 1.68 \\
\hline 4 & $47.46 \pm 0.63^{b, d}$ & $49.78 \pm 3.03^{b}$ & 1.41 & $52.30 \pm 1.30^{d}$ & 1.35 \\
\hline 5 & $41.91 \pm 1.85^{\mathrm{b}, \mathrm{e}}$ & $21.81 \pm 1.11^{c}$ & 3.23 & $16.10 \pm 1.00^{b}$ & 4.37 \\
\hline 6 & $30.58 \pm 3.09^{f}$ & $75.00 \pm 1.68^{d}$ & 0.94 & $36.92 \pm 1.27^{\mathrm{e}}$ & 1.91 \\
\hline 7 & $55.65 \pm 0.30^{c}$ & $84.28 \pm 3.30^{e}$ & 0.84 & $19.12 \pm 0.25^{f}$ & 3.68 \\
\hline 8 & $80.50 \pm 4.83^{9}$ & $65.00 \pm 6.88^{\mathrm{d}, \mathrm{f}}$ & 1.08 & $86.55 \pm 4.61^{9}$ & 0.81 \\
\hline Doxorubicin & $9.35 \pm 0.66^{h}$ & - & nd & $0.5 \pm 0.00^{h}$ & nd \\
\hline Puromycin & $5.32 \pm 0.90^{i}$ & $0.4 \pm 0.02^{\mathrm{g}}$ & 176.03 & $1.15 \pm 0.17^{i}$ & 61.23 \\
\hline
\end{tabular}

Data represent the mean $\pm S D$ of three independent experiments; values with different letters are significantly different at $\mathrm{p}<0.05$

nd not determined, $-100 \mu \mathrm{g} / \mathrm{mL}$ 
the SET method [21]. In this study, the antioxidant activity of compounds was determined using the free radical 2,2'-azino-bis (3-ethylbenzothiazoline-6-sulphonic acid) diammonium salt (ABTS), 2,2-diphenyl-1-picrylhydrazyl (DPPH) and the ferric reducing antioxidant power (FRAP) assays. The use of at least two different assays in evaluating antioxidant activity of plant products has been recommended by Moon and Shibamoto [22].

The antioxidant activity revealed that, the $\mathrm{IC}_{50}$ values of compounds 7, 6 and 2 were significantly different from the $\mathrm{IC}_{50}$ values of ascorbic acid and trolox, which are standard antioxidant agents used as positive controls. The capacity of flavonoids to act as antioxidants in vitro has been previously studied [23]. However, the antioxidant activity of entadanin, a new peltogynoid is here reported for the first time.

In order to ascertain the likely safety of compounds for their potential use, a standard cell-based toxicity assay was performed for cytotoxicity evaluation against Vero monkey kidney cells. In addition, the anti-proliferative activity was assessed on two cancerous cell lines (THP-1 and RAW 264.7). According to the in vitro cytotoxic activity criteria suggested by Syarifah et al. [24], a compound is considered as weakly active if the $\mathrm{LC}_{50} \geq 50 \mu \mathrm{g} /$ $\mathrm{mL}$, moderately active for $10 \mu \mathrm{g} / \mathrm{mL}<\mathrm{LC}_{50}<50 \mu \mathrm{g} / \mathrm{mL}$ and significantly active if $\mathrm{LC}_{50} \leq 10 \mu \mathrm{g} / \mathrm{mL}$ ). Considering this cut-off, the activity obtained with compound $\mathbf{1}$ (ursolic acid) against THP-1 and RAW 264.7 cells could be considered significant. Ursolic acid is a natural pentacyclic triterpenoid carboxylic acid present in a wide variety of plants, including apples, basil, bilberries, cranberries, peppermint, rosemary and oregano [25]. Several pharmacological effects of ursolic acid including antiproliferative properties have been reported in a number of experimental systems [26]. It should be noted that this is the first report on the biological activity of compound 7 , a cyclic homoflavonoid (entadanin), and compound 8 (bis-[(S)-(2,3-dihydroxypropyl)] hexacosanedioate).

\section{Conclusion}

Our findings suggest that among the terpenoid and flavonoid compounds studied, entadanin (compound 7), whose activities are reported here for the first time, possesses extremely interesting antibacterial activity against S. typhimurium. Therefore, this compound could be investigated further for its potential use in the treatment of bacterial diseases, especially gastrointestinal infections caused by S. typhimurium.

\section{Abbreviations}

FCS: fetal calf serum; PBS: phosphate buffered saline; ABTS: 2,2'-azino-bis (3-ethylbenzothiazoline-6-sulphonic acid) diammonium salt; DPPH: 2,2-diphenyl-1-picrylhydrazyl; MTT: 3-(4,5-dimethylthiazol-2-yl)-2,5-diphenyltetrazolium bromide; DMSO: dimethyl sulfoxide; INT: p-iodonitrotetrazolium violet; MHB: Muller Hinton broth; DMEM: Dulbecco's Modified Eagle Medium; FRAP: ferric reducing antioxidant power; TPTZ: tripyridyl triazine.

\section{Authors' contributions}

JPD carried out the experiments and wrote the manuscript. RM, ArTT and AITT contributed to the compound isolation and identification. GDKWF and BTN supervised the chemical part of the study. JNE and LJM supervised the work and provided the facilities for biological activities study. All authors read and approved the final manuscript.

\section{Author details \\ ${ }^{1}$ Phytomedicine Programme, Department of Paraclinical Sciences, Faculty of Veterinary Science, University of Pretoria, Private Bag X04, Onderstepoort, Pretoria 0110 , South Africa. ${ }^{2}$ Department of Biochemistry, Faculty of Sci- ence, University of Dschang, P.O. Box 67, Dschang, Cameroon. ${ }^{3}$ Department of Organic Chemistry, Faculty of Science, University of Yaoundé I, P.O. Box 812, Yaoundé, Cameroon. ${ }^{4}$ Department of Chemistry, Higher Teachers'Training College, University of Yaoundé I, P.O. Box 47, Yaoundé, Cameroon. ${ }^{5}$ Institute of Medical Research and Medicinal Plants Studies (IMPM), Center of Medicinal Plants Studies and Traditional Medicine (CRPMT), P.O. Box 6163, Yaoundé, Cameroon.}

\section{Acknowledgements}

The University of Pretoria provided a postdoctoral fellowship to JPD.

\section{Competing interests}

The authors declare that they have no competing interests.

\section{Availability of data and materials}

"The chemical structures supporting the conclusions of this article are available in the http://pubchem.ncbi.nlm.nih.gov/under the CID number 77-52-1, 522-12-3, 59262-54-3, 948827-00-7, 14218259-0 and 99-24-1. Cell lines are available at: http://web.expasy.org/cellosaurus/ under references: CVCL_0493, CVCL_0006 and CVCL_0059. All other datasets supporting the conclusions of this article are included within the article.

\section{Consent to publish}

This manuscript does not contains any individual person's data.

\section{Ethics statement and consent}

This research did not involve data collected from humans or animals. Entada abyssinica does not belong to the species under CITES, therefore no permission is required to collect and study this plant in Cameroon.

\section{Funding}

The National Research Foundation (NRF) and Medical Research Council (MRC) provided funding to support this study.

Received: 23 February 2016 Accepted: 1 March 2017

Published online: 06 March 2017

\section{References}

1. Hoake JB, Pastorino JG. Ethanol, oxidative stress and cytokine-induced liver cell injury. Alcohol. 2002;27(1):63-8.

2. Wise R. The worldwide threat of antimicrobial resistance. Curr Sci. 2008:95:181-7.

3. Gillet JP, Gottesman MM. Mechanisms of multidrug resistance in cancer. Methods Mol Biol. 2010;596:47-76.

4. Cummins J, Tangney M. Bacteria and tumours: causative agents or opportunistic inhabitants? Infect Agent Cancer. 2013;8(1):11.

5. Fodouop SPC, Simo RT, Amvene JM, Talla E, Etet PFS, Takam P, Kamdje AHN, Mulle JM. Bioactivity and therapeutic potential of plant extracts in cancer and infectious diseases. J Dis Med Plants. 2015:1(1):8-18.

6. Bekele-Tesemma A, Birnie A, Tengnas B. Useful trees and shrubs for Ethiopia. Regional Soil Conservation Unit (RSCU), Swedish International Development Authority (SIDA); 1993. 
7. Haile Y, Delenasaw Y. Traditional medicinal plant knowledge and use by local healers in Sekoru District, Jimma Zone, Southwestern Ethiopia. J Ethnobiol Ethnomed. 2007:3:24.

8. Olajide OA, Alada AR. Studies on the anti-inflammatory properties of Entada abyssinica. Fitoterapia. 2001;72:492-6.

9. Mariita RM, Orodho JA, Okemo PO, Mbugua PK. Antifungal, antibacterial and antimycobacterial activity of Entada abysinnica Steudel ex A. Rich (Fabaceae) methanol extract. Pharmacogn Res. 2010;2(3):163-8.

10. Teke GN, Lunga PK, Wabo HK, Kuiate JR, Vilarem G, Giacinti G, Kikuchi H, Oshima Y. Antimicrobial and antioxidant properties of methanol extract, fractions and compounds from the stem bark of Entada abyssinica Stend ex A. Satabie. BMC Complement Altern Med. 2011;11:57.

11. Freiburghaus AF, Steck HP, Brun R. Bioassay-guided isolation of a diastereoisomer of kolavenol from Entada abyssinica active on Trypanosoma brucei rhodesiense. J Ethnopharmacol. 1998;61:179-83.

12. Asfaw D, Olaf K, Martin GS, Günter M, Franz B, Dawit A, Erns H. A diterpene, a flavonoid glycoside and a phytosterol from Entada abyssinica stem bark. Monatshefte Chemie. 2000;131:401-8.

13. Nyasse B, Ngantchou I, Tchana EM, Sonké B, Denier C, Fontaine C. Inhibition of both Trypanosoma brucei bloodstream form and related glycolytic enzymes by a new kolavic acid derivative isolated from Entada abyssinica. Pharmazie. 2004:59:873-5.

14. Melong R, Kapche FGFWD, Feussi TM, Laatsch H. A new aggreceride analogue and a peltogynoid isolated from the stem bark of Entada abyssinica (Fabaceae). Nat Prod Comm. 2014;9(10):1499-502.

15. Dzoyem JP, McGaw LJ, Eloff JN. In vitro antibacterial, antioxidant and cytotoxic activity of acetone leaf extracts of nine under-investigated Fabaceae tree species leads to potentially useful extracts in animal health and productivity. BMC Complement Altern Med. 2014;14:147.
16. Dzoyem JP, Eloff JN. Anti-inflammatory, anticholinesterase and antioxidant activity of leaf extracts of twelve plants used traditionally to alleviate pain and inflammation in South Africa. J Ethnopharmacol. 2015;160:194-201.

17. Metwally AM, Omar AA, Harraz FM, El Sohafy SM. Phytochemical investigation and antimicrobial activity of Psidium guajava L. leaves. Pharmacogn Mag. 2010;6(23):212-8.

18. Liu J. Pharmacology of oleanolic acid and ursolic acid. J Ethnopharmacol. 1995:49(2):57-68.

19. Fontanay S, Grare M, Mayer J, Finance C, Duval RE. Ursolic, oleanolic and betulinic acids: antibacterial spectra and selectivity indexes. J Ethnopharmacol. 2008;120(2):272-6.

20. Huang D, Boxin OU, Prior RL. The chemistry behind antioxidant capacity assays. J Agric Food Chem. 2005;53(6):1841-56.

21. Becker K, Schroecksnadel S, Gostner J, Zaknun C, Schennach H, Uberall F, Fuchs D. Comparison of in vitro tests for antioxidant and immunomodulatory capacities of compounds. Phytomedicine. 2014;21 (2):164-71.

22. Moon JK, Shibamoto T. Antioxidant assays for plant and food components. J Agric Food Chem. 2009;57:1655-66.

23. Pietta PG. Flavonoids as antioxidants. J Nat Prod. 2000:63(7):1035-42.

24. Syarifah SMM, Nurhanan MY, Haffiz JM, Ilham AM, Getha K, Asiah O, Norhayati I, Sahira HL, Suryani SA. Potential anticancer compound from Cerbera odollam. J Trop For Sci. 2011;23:89-96.

25. Ikeda Y, Murakami A, Ohigashi H. Ursolic acid: an anti- and pro-inflammatory triterpenoid. Mol Nutr Food Res. 2008;52(1):26-42.

26. Novotny L, Vachalkova A, Biggs D. Ursolic acid: an anti-tumorigenic and chemopreventive activity minireview. Neoplasma. 2001;48:241-6.

\section{Submit your next manuscript to BioMed Central and we will help you at every step:}

- We accept pre-submission inquiries

- Our selector tool helps you to find the most relevant journal

- We provide round the clock customer support

- Convenient online submission

- Thorough peer review

- Inclusion in PubMed and all major indexing services

- Maximum visibility for your research

Submit your manuscript at www.biomedcentral.com/submit
O Biomed Central 